\title{
The Influence of Occupational Safety and Health on Job Satisfaction and Organizational Commitment of Hospital Nurses in Makassar City
}

\author{
Andi Niartiningsih ${ }^{1}$, Irwandy ${ }^{1}$, Masyitha Muis ${ }^{1}$ \\ ${ }^{1}$ Lecturers of Departement of Hospital Management, Faculty of Public Health, Hasanuddin University
}

\begin{abstract}
Occupational safety and health is a system used to prevent the possibility that will arise due to work accidents and prevention of the emergence of diseases caused by work relationships with employees in the environment. This study aims to analyze the effect of occupational safety and health on job satisfaction and organizational commitment of hospital nurses in the city of Makassar. This type of research is quantitative research using observational studies with cross sectional study design and using path analysis. Sampling using stratified random sampling so that the sample in this study were nurses in charge of Inpatient Installation, IGD, ICU and OK, amounting to 230 respondents. The results showed there was an effect of occupational safety and health variables on job satisfaction $(\mathrm{p}=0.001)$, there was an effect of occupational safety and health on organizational commitment $(p=0.001)$, there was an effect of job satisfaction on organizational commitment $(\mathrm{p}=0.001)$, and there was no the effect of occupational safety and health on organizational commitment through job satisfaction (coefficient $=0.419$ ). It is recommended to the hospital management to encourage nurses to work in an innovative way and provide opportunities in making decisions that pose a risk to the welfare of employees by providing benefits, prioritizing comfort and safety of nurses' work in order to increase nurse job satisfaction so that it has an impact on improving the quality and performance of the hospital.
\end{abstract}

Keywords: Occupational Safety and Health, Job Satisfaction, Organizational Commitment

\section{Introduction}

Job satisfaction also has a direct influence towards organizational commitment Companies or organizations that fulfill the desires or desires of employees will increase their work productivity either through incentives, support, recognition and rewards that are assessed on the performance results.According to Mathis \& Jackson ${ }^{1}$ states that job satisfaction reflects one's feelings towards work, when someone is satisfied with their work then they will be more committed to the organization.

Research conducted by Sembe and Amos ${ }^{2}$ entitled "The Effect of Selected Occupational Health and Safety Management Practices on job satisfaction of Employees at University Campuses in Nakuru Town, Kenya". His findings reveal that Occupational health and safety management practices lead to increased job satisfaction among employees. Ward ${ }^{3}$ in his research entitled The impact of health and safety management on organizations and their staff, states that this study examines the impact of proactive OHS management on organizational performance, employee attitudes towards work and their organization, and employee health and welfare. At the organizational level, the proactive $\mathrm{OSH}$ approach is associated with more positive organizational attitudes and perceptions of the safety climate. At the level of individual employees, a more positive perception of safety and organizational attitude is associated with better health and well-being ${ }^{4-6}$.

RSUP Dr. Tadjuddin Chalid, Makassar City Hospital and Stella Maris Hospital are class B general hospitals in Makassar City and have been accredited. Based on a preliminary study with unstructured interviews with informants, namely the Head of Occupational Safety and Health \& infection prevention and control in December 2019 to January 2020, it was found that workplace 
accidents that occurred in officers, especially nurses in 2017-2019, were punctured by used syringes in inpatient installations, emergency room, ICU and operating room. This happens because officers who do not comply with SOPs such as not wearing Personal Protective Equipment (PPE), and using repeated needles. In addition to conducting interviews with the head of Occupational Safety and Health, while conducting interviews with nurses some of them did not know Occupational Safety and Health so it cannot be known how the success of Occupational Safety and Health implementation.

\section{Materials and Method}

\section{Design of Research and Location}

This research was conducted at the Dr. Tadjuddin Chalid, Kota Makassar Hospital and Stella Maris Hospital. This type of research is quantitative research using observational studies with the Cross Sectional Study approach.

\section{Method of collecting data}

The instrument used in data collection was a questionnaire, regarding the independent variables in the form of occupational safety and health while the dependent variable was the variable job satisfaction and organizational commitment.

\section{Data analysis}

The data analysis technique of this study used univariate analysis, bivariate with Chi Square test, and multivariate analysis with path analysis with Statistical Package for the Social Sciences (SPSS) 22.0 for windows program.

\section{Results}

Univariate Analysis

Table 1: Frequency Distribution of Respondents Based on Research Variables in RSUP Dr. Tadjuddin Chalid, Kota Makassar Hospital and Stella Maris Hospital

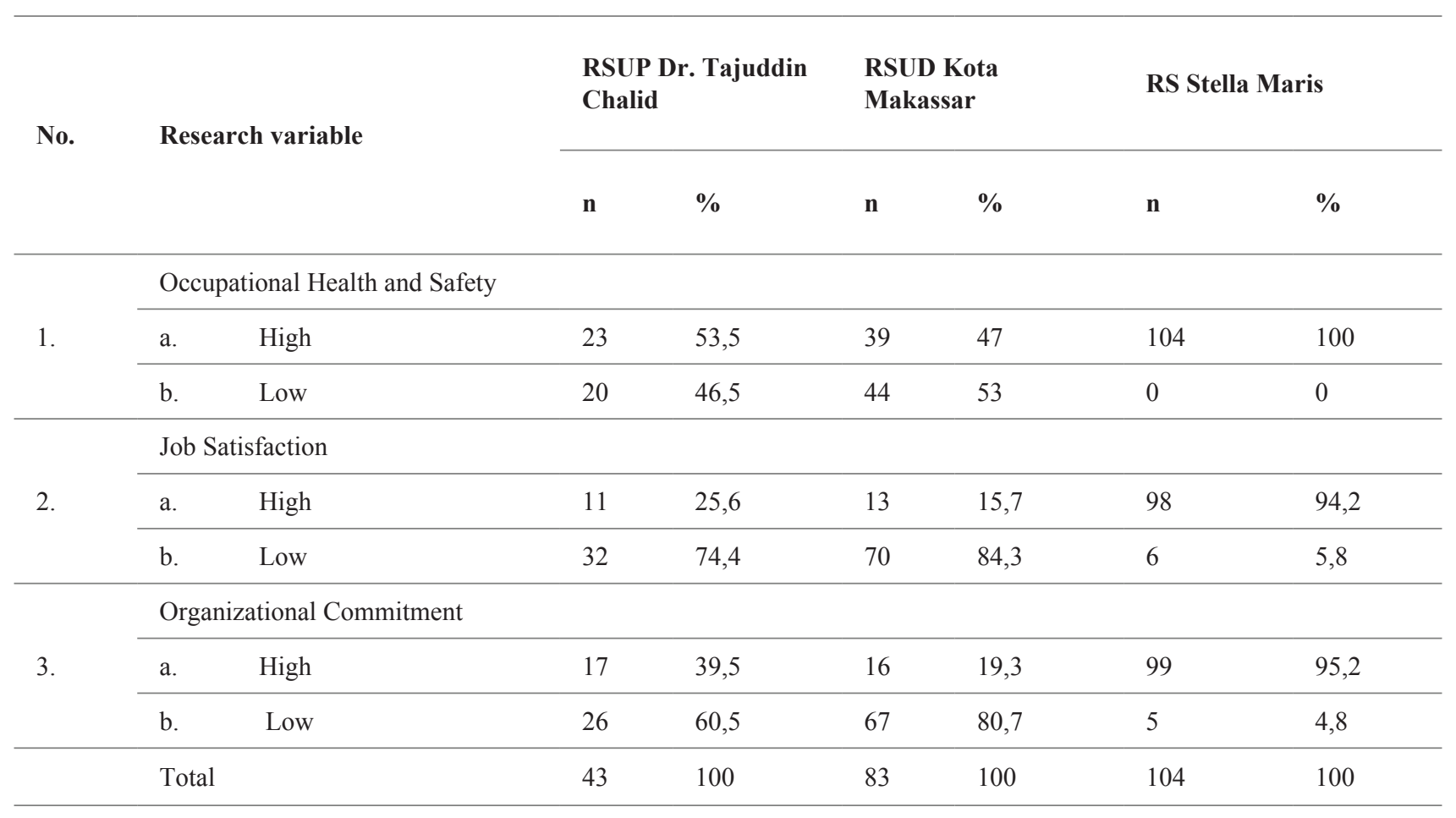

Primary Data Sources 2020

Amounting to $94.2 \%$ stated high for the variable job satisfaction and by $95.2 \%$ stated high for the variable organizational commitment. 


\section{Bivariate Analysis}

Table 2 shows the relationship between the independent variable and the dependent variable. Based on the results of the analysis it can be seen the influence of occupational safety and health variables on job satisfaction in Dr. Tadjuddin Chalid, Kota Makassar Hospital and Stella Maris Hospital.

Table 2: Comparison of Sig. in the Anova Table to Test the Effect of Occupational Safety and Health Variables on Job Satisfaction and Organizational Commitment Nurse General Hospital in Makassar City

\begin{tabular}{|c|c|c|c|c|}
\hline \multirow[b]{2}{*}{ No. } & \multirow[b]{2}{*}{ Variable } & \multicolumn{3}{|c|}{ Sig Value. (Anova Table) } \\
\hline & & $\begin{array}{l}\text { RSUP Dr. } \\
\text { Tadjuddin } \\
\text { Chalid }\end{array}$ & RSUD Kota Makassar & RS Stella Maris \\
\hline 1. & Occupational Health and Safety & 0,001 & 0,001 & 0,001 \\
\hline 2. & Job Satisfaction & 0,001 & 0,001 & 0,001 \\
\hline 3. & Organizational Commitment & 0,001 & 0,001 & 0,001 \\
\hline
\end{tabular}

Primary Data Sources 2020

There is an influence of occupational safety and health variables on organizational commitment Dr. Tadjuddin Chalid with $\mathrm{p}=0.001<0.05$ and $\mathrm{r}=0.762$, Kota Makassar Hospital with $\mathrm{p}=0.001<0.05$ and $\mathrm{r}=0.735$, Stella Maris Hospital with $\mathrm{p}=0.001<0.05$ and $\mathrm{r}$ value $=0.801$ and there is an effect of the variable job satisfaction on organizational commitment Dr. Tadjuddin Chalid with $\mathrm{p}=0.001<0.05$ and $\mathrm{r}=0.796$, Kota Makassar Hospital with $\mathrm{p}=0.001<0.05$ and $\mathrm{r}=0.727$, and Stella Maris Hospital with $\mathrm{p}=0.001<0.05$ and value $\mathrm{r}=0.944$.

\section{Multivariate Analysis}

Table 3 explains how closely and indirectly the influence between variables, namely between occupational health and safety variables on organizational commitment variables through job satisfaction.

Table 3: Results of Analysis of the Pathway between Occupational Health and Safety, Job Satisfaction, and Organizational Commitment of Nurses in General Hospitals in Makassar City

\begin{tabular}{lccc}
\hline Variable & Coefficient & P Value & Explanation \\
\hline $\begin{array}{l}\text { Occupational Health and Safety à } \\
\text { Job Satisfaction }\end{array}$ & 0,892 & 0,001 & Direct \\
\hline $\begin{array}{l}\text { Occupational Health and Safety à } \\
\text { Organizational Commitment }\end{array}$ & 0,376 & 0,001 & Direct \\
\hline $\begin{array}{l}\text { Job Satisfaction à } \\
\text { Organizational Commitment }\end{array}$ & 0,470 & 0,001 & Direct \\
\hline $\begin{array}{l}\text { Occupational Health and Safety à } \\
\text { Job Satisfaction à Organizational Commitment }\end{array}$ & 0,419 & Indirect \\
\hline
\end{tabular}

Primary Data Sources 2020 


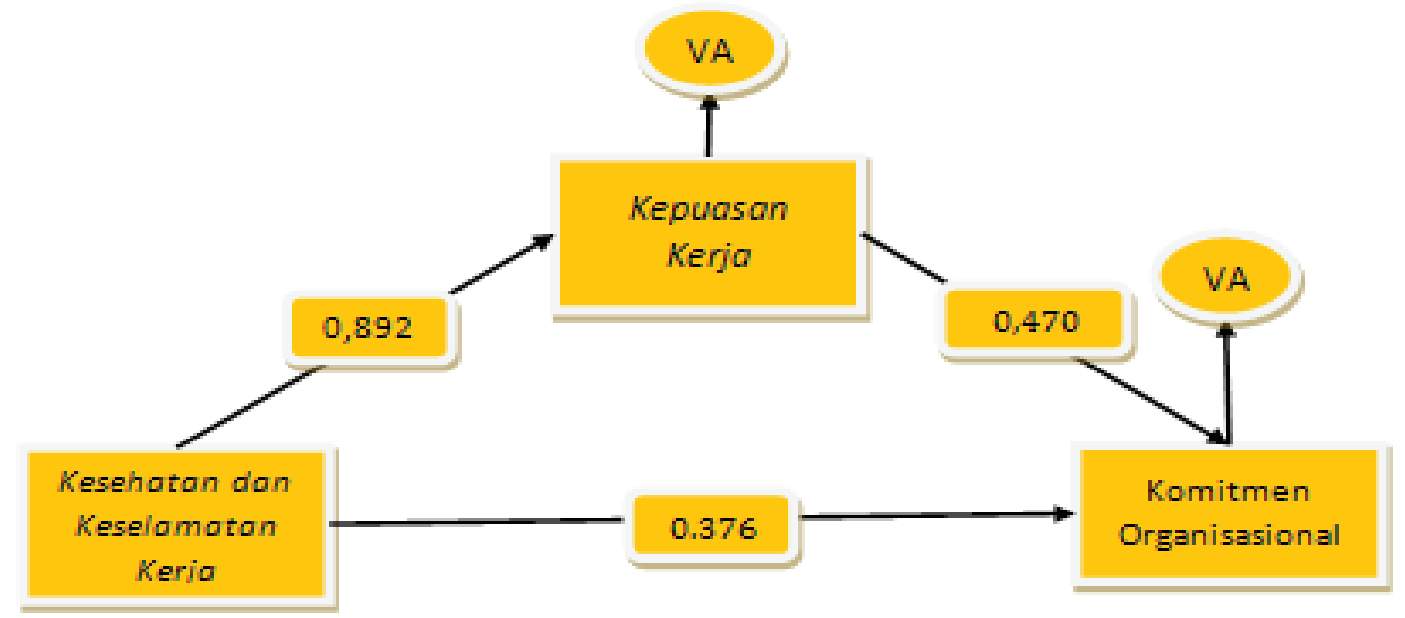

The path analysis is based on a path diagram between occupational health and safety to organizational commitment through job satisfaction shown in the figure below:

The effect of job satisfaction on organizational commitment obtained $\mathrm{p}=0.001<0.05$ with a large influence of 0.470 which means that if job satisfaction rises by 1 point, organizational commitment will increase by 0.470 points. Whereas there is no effect of occupational health and safety on organizational commitment without going through job satisfaction because the greater indirect path coefficient $=0.419$ than the direct path coefficient between work health and safety on organizational commitment $=0.376$.

\section{Discussion}

Occupational safety and health is one of the most important things to consider in the company because this is something that must be guaranteed given to employees in supporting the success of their performance. Therefore, several dimensions that must be considered in the occupational safety and health of employees are Commitment management, Communication, Priority of safety, Safety rules and procedures, Supportive environment, Involvement, Personal priorities and needs for safety, Personal appreciation of risk and Physical work environment ${ }^{3-6}$

Regression test results of Hospitals in Makassar City show that the p-value (0.001), this means that the null hypothesis (Ho) is rejected, meaning that there is an influence between occupational safety and health with nurse job satisfaction. Both these variables have an effect strengthened by a statement according to
Mangkunegara $^{7}$ which states that every employee to obtain a guarantee of occupational safety and health both physically, socially, psychologically can increase job satisfaction.

Occupational safety and health variables indicate that most hospital nurses stated that they disagreed with the statement given enough time to finish work safely (76.5\%), the suggestions I gave related to Occupational safety and health would be considered (83\%), the hospital gave protection of employees against physical and emotional losses $(80.9 \%)$. Special attention to the safety and health of employees at the hospital is a natural thing, but in reality what happens in the field shows attention to occupational safety and health is relatively less comparable to the work risks faced.

This research is in line with what was done by Yusuf et $\mathrm{al}^{8}$, namely $\mathrm{K} 3$ has a significant effect on job satisfaction. The coefficient of entry with a positive standard value of 0.351 indicates that as $\mathrm{K} 3$ increases, job satisfaction will also increase. Other research, namely research conducted by Sembe $\& \mathrm{Amos}^{3}$ states the findings reveal that safety and health management practices lead to increased job satisfaction among employees.

Regression test results for Hospitals in Makassar City show that the p-value (0.001) means that the null hypothesis (Ho) is rejected, meaning that there is an influence between occupational safety and health with 
the organizational commitment of nurses. Because the significance value or $p$ value of $0.001<0.05$, it means that statistically there is a significant influence between occupational safety and health with organizational commitment of nurses. Organizational members who have a higher level of commitment will be more enthusiastic and motivated to carry out their duties or work.

Research supported by the results above is a study conducted by Amponsah Tawiah and Justice'. These findings reveal a positive and significant relationship between the work of health and safety management, and affective, normative, and ongoing commitment. Occupational Safety and Health is important to guarantee employee commitment. The factors that influence nurses' commitment to aspects of OSH regulations are implemented well, OSH obligations and needs, work location conditions, employee perceptions and benefits provided by the hospital. Therefore, the hospital needs to be more active in paying attention to the factors that make employees' commitments at each work level different so that evaluation can be carried out in the future. The results of this study support the theory and previous studies that examine the effect of the application of OSH to organizational commitment namely ${ }^{10,11}$.

Regression test results at Hospital in Makassar showed that the p-value (0.001) meant that the null hypothesis (Ho) was rejected, meaning that there was an influence between job satisfaction and organizational commitment of nurses. Because the significance value or $\mathrm{p}$ value of $0.001<0.05$, it means that statistically there is a significant influence between job satisfaction with organizational commitment of nurses. Employees who are satisfied with what is obtained from the company will provide more than what is expected by companies with high commitment and he will continue to try to improve performance.Job satisfaction variable shows that most hospital nurses expressed less agree on the statement I was satisfied with the promotion system set according to the length of service, performance and abilities performed in the hospital (90.9\%), I was satisfied with the way the hospital apply a policy on sanctions in the promotion of office if violated (sanctions in the form of reprimand or summons) (86.5\%), I feel satisfied because the leadership gave a complete answer to questions and complaints (83.5\%). Other research, namely research conducted by
Liao $^{12}$ states that satisfaction also has a positive influence on organizational commitment $(\beta=0.33, \mathrm{p}<0.01)$ on all significant models. The average value of job satisfaction and organizational commitment is on the moderate side. Significant positive relationships are being found among the aspects of job satisfaction, demographic factors, and organizational commitment. Supervision, salary, overall job satisfaction, age, and years of service are significant predictors of organizational commitment. The results show support for the first hypothesis because all aspects of job satisfaction are significantly related to organizational commitment at the 0.01 and 0.05 levels. These results are consistent with the results of research from Naderi ${ }^{13}$ in the study conducted found a positive and significant relationship between job satisfaction with organizational commitment.

Based on the results of the analysis conducted using path analysis to see the direct effect and the indirect effect between variables, it was found that the indirect path coefficient between occupational safety and health on organizational commitment through job satisfaction is 0.419 and the direct path coefficient between work safety and health on job satisfaction which is 0.892 . then the direct path coefficient is greater than the indirect path coefficient which is $0.892>0.419$ meaning indirectly occupational safety and health through job satisfaction does not have a direct influence on organizational commitment. Research conducted by Crow et $\mathrm{al}^{14}$ and Eslami \& Gharakhani ${ }^{15}$ which shows that job satisfaction has a positive and significant influence on organizational commitment.

Based on the results of research at three public hospitals in Makassar City, it was found that Stella Maris Hospital is a hospital that has an occupational safety and health effect on job satisfaction and organizational commitment of nurses that is greater than Tadjuddin Chalid General Hospital and Makassar City Hospital. This is in accordance with the respondent's answer stating that the existing work facilities are adequate related to occupational safety and health, so that employees at work can create job satisfaction at Stella Maris Hospital, such as a safe and comfortable work environment, suitable work protection equipment , supporting temperature and lighting conditions and health insurance provided, so that employees at work feel satisfied and comfortable. 


\section{Conclusions}

Based on the results of the study, researchers formulated the following conclusions: There is an influence on occupational safety and health on job satisfaction and organizational commitment of nurses, job satisfaction affects organizational commitment and occupational safety and health does not affect the organizational commitment of nurses through nurse job satisfaction. Based on the research results and conclusions that have been formulated.

Ethical Clearance- Taken from University ethical committee

\section{Source of Funding- Self}

\section{Conflict of Interest- Nil}

\section{References}

1. Mathis, R. L., \& Jackson, J. H. Human Resource Management edisi 10. Jakarta: Salemba Empat. 2011.

2. Sembe, F., \& Amos, A. Effect of Selected Occupational Health and Safety Management Practices on Job Satisfaction of Employees in University Campuses in Nakuru Town, Kenya. Journal of Human Resouce Management, 2017; 5(5), 70-77. https://doi.org/doi:10.11648/j. jhrm.20170505.11

3. Ward, J., Haslam, C., \& Haslam, R. The Impact of Health and Safety Management on Organizations and Their Staff. Loughborough University. 2008.

4. Posmaningsih, D.A., Aryasih, G.A.M., Hadi, M.C., Marwati, N.M., Mallongi, A.. The influence of media booklet in behavior change of waste management in elementary school students, South Denpasar, Bali. Indian Journal of Public Health Research \& Development. 2018.

5. AB Birawida, M.Selomo and A. Mallongi, Potential hazards from hygiene, sanitation and bacterium of refill drinking water at Barrang Lompo, IOP Conference Series: Earth and Environmental Science, vol: 157, issue : 1, 2018-06-1, Conference Proceeding.

6. Endah Yani, R.W., Mallongi, A., Andarini, S., Prijatmoko, D., Dewanti, I.R. The effect of zinc saliva on the toddlers nutritional status, Journal of International Dental and Medical Research, 2016; vol: 9, issue : 1, 01-01

7. Mangkunegara. Manajemen Sumber Daya Manusia. Bandung: Remaja Rosda Karya. 2002.

8. Yusuf, R. m., Anis, E., \& Oci, N. S. The Influence of Occupational Safety and Health on Performance. American Journal of Economics, 2012; 136-140. https://doi.org/doi:10.5923/j. economics.20120001.30

9. Amponsah, T.K., \& Justice, M. Occupational Health and Safety and Organizational Commitment.. OSHRI, 2016; 7, 225-230. https://doi.org/http:// dx.doi.org/10.1016/j.shaw.2016.01.002

10. Kaynak, R., Toklu, A. T., Elci, M., \& Toklu, İ. T. Effects of Occupational Health and Safety Practices on Organizational Commitment, Work Alienation, and Job Performance : Using the PLSSEM Approach. 2016; 11(5), 146-166. https://doi. org/10.5539/ijbm.v11n5p146

11. Kwesi, \& Mensah. Employee Motivation and Work Performance: A Comparative Study of Mining Companies in Ghana. Journal of Industrial Engineering and Management, 2016; 9, 255-309.

12. Liao, P. W. Exploring the Impacts of Labor Migration and Job Satisfaction on Organizational Commitment of Foreign Workers in Taiwan's Construction Industry:Employe Ability as a Moderator. American Journal of Industrial and Business Management, 5, 2015; 148-153. https://doi.org/doi:http://dx.doi.org/10.4236/ ajibm.2015.53016

13. Naderi, A. N. Teachers: Emotional Intelligence, Job Satisfaction, and Organizational Commitment. Journal of Workplace Learning, 2011; 24(4), 259269.

14. Crow, M. S., Lee, C., \& Joo, J. Organizational Justice and Organizational Commitment among South Korean Police Officers. Policing: An International Journal of Police Strategies \& Management, 2012; 35(2), 402-423.

15. Eslami, J., \& Gharakhani, D. Organizational Commitment and Job Satisfaction. Journal of Science and Technology, 2012; 2(2), 85-91. 